\title{
AFTERWORD: LOOKING BACK, MOVING FORWARD
}

There is a temporal dimension to an afterword that echoes its structural position in a book, providing a perch from which one can cast an eye backward. As a temporal device, it traditionally says something about what one has just read, not as conclusion or summary but as a description of the processes that have led to the creation of the book itself. However, my approach in this afterword takes a different tack in seeking to converse with some of the central ideas presented here in ways that also look forward. It offers me an opportunity to think alongside some of the key concerns developed across the chapters to see how they can open up new trajectories of inquiry, formations of thought, and ecologies of practice.

Explorations of Self invites inquiry into the nature of self and its relationship to the figure of the teacher and teaching practice. It calls on us to be attentive to the ways in which who we are can act as a source for understanding what we are and what we $d o$. When I was reading these chapters I was, as I'm assuming many readers were as well, reminded of both who and what I am and the distinctions I make between them. As many of the contributors here suggest, making such distinctions between who and what, however, can be fraught with assumptions that replicate dualist conceptions of the world (Bai et al., Sellman). Other authors suggest that self and identity are synonymous, thus insisting that teacher identities are always imbricated with the self (Lyle), while still others see the friction between them (Zhao). Some see self as a process which provides a rich ground for exploring how selves and practices are conditioned by larger trajectories of culture (Ritter) trajectories which actually shape the very conception of self (Ergas and Ragoonaden). Other contributors foreground the centrality of narrative and the arts in formations of the self as central to overcoming a learned dividedness (Lyle, Kitchen), while others explore the conundrums faced within the self-study of practice (Pinnegar and Hamilton). Still others situate the self within a project of mindfulness as key to developing certain skills, such as CCK (Hulburt et al.) or to developing an ecological self (Albrecht). Others suggest that there is an ontological basis to teaching itself (Vlieghe and Zamojski), thus making who and what we are coterminous, while yet others eschew ontological framings of self altogether, viewing the self as "states of mind" (Ergas). Through demonstrating such variety of perspective, what these chapters do collectively is stake different claims about what or who the 
self is, who or what the teacher is, and what explorations of either - or both have to offer teaching and teacher education.

Where these stakes are planted by individual contributors - for example, in the languages of Buddhism, psychology, philosophy, cognitive science, indigenous thought, neuroscience, and the authors' own experiences - matter deeply to one's own sense of self, not only to abstract conceptions of that self but also how one relates such conceptions to one's own life. The chapters thus beckoned me to think about my "self" and my teaching practice through quite different frameworks and vocabularies than I usually do, and I found myself remembering bits and pieces of my life (both professional and personal) as they resonated with some of the words I was reading. I caught myself frequently asking, Am I self who is a teacher? Am I teacher who has a separate self? What does one study when one studies a "self"? Is a "self" something that is "inner" or inside of something else? Where am $I$ when I teach? In being reminded of both who and what I am as I read the book, I kept returning to how aspects of my teaching life resonated with the various accounts that were offered. I found the "who" and "what" question, along with the queries about "inner" and "outer," beginning to entwine themselves around certain biographical musings.

I began teaching elementary school over 30 years ago in my mid-twenties, and when I think of that time, my practice was consciously shaped not only by what I wanted to be as a teacher but also who I thought I could be as "me." No bullshit, fully present, meeting students with compassion and care, truthfulness, and understanding; I did not "love children," nor did I assume that my work was a calling or vocation, nor did I go into elementary education because of a love of my subject (which was art history). I became engaged in teaching because I thought education (not teaching, not school) could change the course of a life; I wanted somehow to be part of that change and thought I would enjoy being part of the change, even if I did not know how to do it or even if I could or should do it - and I was very aware even then that lurking somewhere uncomfortably was an egoist desire to change others, just as I had been changed through my education - a desire with which I still struggle. Thus while my work was and still is personal, in the sense I feel committed to my students and to the integrity of my work as an academic, there is a lot about it that is not. Equally, my life is not my teaching. I am not trying to be "me" through my teaching the way I did so long ago, nor do I try to be a "teacher," as if I can inhabit (or even work toward) some predefined or ideal position. Some of the material I teach I am passionate about, while other material much less so. My engagement as a teacher lies for me now (at least in how I conceive it), more in the handling of the material in relation to the students, each one and each group quite different from the next, seeing my practice initially as one of curating and holding encounters that optimally enable students to make their own relationship to the material at hand. In this, there has been a thread linking, 
however tenuously, my kindergarten class to my doctoral seminar. This way of doing and thinking about my practice means that I have to continuously evaluate how and when to intervene, intercept, move my body, pose a question, interact, and challenge, and equally how and when to echo what students' say, back off, reframe, still my body, and silently reflect. It is a constant dance of judgment, of hunches, of risk-taking, of uncertainty. I have found that it is the practice that has made me a teacher - not the other way around.

The trajectory of my musings here indicates a couple of things that I think resonate with some of the concerns of the book. First, that who I am and what I am do not always come together, not because of any dualism but because they speak of different ways of thinking of our existence - our actual living - in the world with others. According to Arendt, who some of the contributors also draw upon, who I am as a unique being in the world is not to be conflated with what I am (my achievements, my profession, my socioeconomic background, my racial identifications, my sexuality, my gender - all these "mys"!). This is not to say that "what" one is is unimportant to one's life. While what I am does indeed profoundly shape the conditions of that life, it is nonetheless never fully determinant of who I am. Who I am is a radically decentred experiential subject, one who is always more than the sum of its identities, in excess of the social scripts through which we all operate. This "more than," however, is not necessarily an invocation of a transcendent ego or self but simply consists in a refusal to assign causality to the various positionings on the social grid we might occupy, be these categories of race, class, gender, ethnicity, and sexuality or the category of teacher itself. Brian Massumi (2002) refers to this causal thinking, so often seen in identity politics, as something that shuts down the capacity to think about how our singular experiences of the world create change and transformation beyond our location on the grid. Thus, no matter how many intersecting points I occupy on the grid (as woman, white, university teacher), they can never add up to a life; social categories simply cannot fully capture the rich intensities of experience that constitute who I am in my singularity.

Secondly, what struck me about my musings is that they could only have been written now. How I conceptualize myself here and now is not, I know, how I thought of myself and my teaching then. I have experienced, read, engaged, and struggled with states of mind, physical illness, intense feelings, imaginative moments, and significantly, the ideas of others: my professional/ personal life has thereby emerged through the way I continue to encounter the world: the "self" never seemingly finding a fixed point once and for all. Even through meditation practice, it is not a "self" I uncover through, or as, my "mind," but the waves of attachments and felt intensities that take form, take shape, in thoughts and bodily sensations. An abiding awareness of these is about what Dogen calls "forgetting oneself," as Bai et al. remind us. 
Meditation, for me, is not about going to an "inner" reality, contrasting it with an "outer" one; this language too easily fixes the subject into a "self" whose interiority is somehow prior to its engagement with the world. It is rather more a case of signaling the directionality of our attention: thus "introspection" as vita contemplativa (Ergas) is more about the journey and less about the destination. Like a road trip, what we are exploring when we explore the self, on these terms, is not some "inner" life of the self, but the very experiential textures of living, which factor into how we come to draw a line between inner and outer in the first place. Thus in this sense, exploring self is a complex act of simultaneously allowing the self to step aside while exploring the entanglements (Vleighe and Zamojski) each of us are necessarily caught up in.

In reading these chapters, however, I was not only "reminded" of certain aspects of myself as "self" and/or "teacher" but also challenged to think, reflect, and query who I potentially might become. As the chapters together cut across a wide range of theoretical traditions, disciplinary boundaries, and conceptual assumptions, they allowed me a space to reflectively inquire into the limits of self and teacher beyond the grid of positionality altogether. Where I plant my own stakes, then, as you can probably surmise from what I have already written, lies in the shifting sands of practice and encounter what we do, and how we live - where even terms such as "self" and "teacher" begin not so much to collapse into a pool of quicksand, but are assembled and reassembled with each gust of wind on the sand's surface, albeit with some gusts stronger than others.

Out of my own scholarly reading, my own teaching practices, and my own life experiences - a method mirroring that of the authors - I view self and teacher not so much as nouns or substances, but as constellations that emerge out of the very messy relational networks of living a life with things, objects, humans, and other forms of animate life. Our commonplace phrase of being a teacher seems to be misleading, in that it is not something or someone that I am or even aspire to be. Despite my beginnings in teaching as being informed by what and who I wanted to be, I think I can safely declare at this stage in my life: I am not a teacher! This statement comes with a freeing sense of disidentification with social scripts, with prescriptive ways of being and doing. Instead, I understand the practices of teaching as enactments that occur to create a certain space and time with others and that those practices converge to make a teacher out of "me." This is no transactional view of teaching, whereby "teaching" happens when there is "learning" present. Rather, teaching involves a host of embodied practices that are directed toward creating and curating educational encounters with the world with and for others. As an ecology of practices, teaching is not guided by or masterminded by a "teacher self"; rather, the practices create the possibility for the teacher to emerge. Thus, it is in and through these practices that teaching becomes something I attach myself to and call it "me." In this sense, as I 
intimated earlier, I am not a teacher prior to the practices, encounters, and engagements I partake in with others; I am instead constantly becoming a teacher through them.

Thus, Exploring Self offers us trajectories for investigating our senses of self beyond "essence" and our senses of what it means to teach and to teach about teaching. The book's expansive range of views has allowed me to think, consider, reflect, and imagine my own teaching practices and how they intersect not only with who I think I am but also where I might become. I have tried to capture in some way my very personal encounter with the ideas presented here in order to demonstrate precisely this movement of becoming, the temporalities it entails, and the openings it makes possible. The time for looking back is closing; the time for moving forward is now beginning.

\section{Reference}

Massumi, B. (2002). Parables for the virtual: Movement, affect, sensation. Durham, NC: Duke University Press. 